\title{
Comparison of Two Sequential Extraction Procedures for Trace Metal Partitioning in Ore Samples From the Keban Region in Elaziğg, Turkey
}

\author{
Elif Varhan Oral \\ Dicle University, Faculty of Pharmacy, Department of Analytical Chemistry, \\ 21280 Diyarbakır, Turkey
}

\section{INTRODUCTION}

Metal mobility powerfully relies on the chemical forms or types of binding of the element in the environment. Determination of total metal concentration in solids does not totally inform about the mobility of metals (1-3). However, it is important to assess the heavy metal burden because metal cations in solids can exist in a variety of physico-chemical forms, i.e., simple or complex ions, easily exchangeable ions, organically bound, occluded by or coprecipitated with metal oxides or carbonates or phosphates and secondary minerals, or ions in crystal lattices of primary minerals (1, 4-7). Besides, it is difficult to determine the particular chemical species or binding forms (8-11). For that reason, sequential extraction procedures are usually practiced since they provide information about the origin, mode of formation, mobilization and presence of trace metals $(1,12)$. The extractants serve to increase the reactivity of the sequential extraction schemes (SESs) and of the obtained fractions corresponding to metal association forms with lesser mobility. In sequential extraction schemes, the commonly used extractants separate the following groups: unbuffered salts, weak acids, reducing agents, oxidizing agents, and strong acids (13, 14)

In a literature survey, it was found that various chemical extractants can be used and there are numerous sequential extraction

\footnotetext{
*Corresponding autbor.

E-mail: evarban@dicle.edu.tr

Tel: $+904122411000 / 7543$

Fax: +90412248 8499
}

\begin{abstract}
The objective of this research was to compare two sequential extraction procedures, modified Tessier and revised BCR, for the fractionation study of $\mathrm{Fe}, \mathrm{Cu}, \mathrm{Co}$, $\mathrm{Pb}, \mathrm{Zn}$, and $\mathrm{Mn}$ in ore samples obtained from the Keban Region, Turkey. The efficiency and suitability of these procedures and their corresponding extraction steps for partitioning the heavy metals bound to the solid forms were tested. Metal analysis was carried out by inductively coupled plasma optical emission spectrometer (ICP-OES). The two procedures were examined and showed that there are differences in the bonding forms of the metals to ore and in the properties of the reactants used. Because of these differences, the amount of metals passing through the solution are different in the two procedures.
\end{abstract}

schemes based on the fractions. These vary in the use of extractants, objective phases, and the order of separation of each particular form of the metal. (15-19) Tessier et al. (19) proposed a five-step procedure which was one of the first SESs and later, most schemes used the fivestep procedure $(13,20-22)$. This scheme has been extensively utilized for the separation of exchangeable metals, metals bound to carbonates, iron manganese oxides, organic matter; and for residual metal which is referred to as exchangeable, weakly absorbed, hydrous oxide-bound, organic bound, and lattice material components, respectively (23-27). One of the other most used sequential extraction procedures is the modified Tessier procedure. The difference of the modified Tessier procedure is a four-step extraction: exchangable, carbonates, organic matter and sulfides, and residual (13).

The Community Bureau of Reference (BCR) procedure strongly resembles the Tessier procedure, with the major difference in the first fraction of the procedure. Ure et al. $(24,27,28)$ integrate the exchangeable and carbonate-bound steps in the first fraction instead of separately calculating them. Therefore, a three-step SES has been developed as a result of this study in which the metals are divided into acid-soluble/exchangeable, reducible, and oxidizable fractions $(1,13,23,29)$.

The aim of the current study was to compare the two sequential extraction schemes of the modified Tessier procedure $(13,30)$ and the revised BCR procedure $(1,13$, $23,29)$ for evaluating metal fractionation in ore samples from the Keban region, Turkey. The extraction steps for heavy metal-bound fractions and the efficiency and suitability of the mentioned procedures were tested.

\section{EXPERIMENTAL}

\section{Instrumentation}

The metal analyses were performed using an Optima ${ }^{\mathrm{TM}} 2100 \mathrm{DV}$ inductively coupled plasma optical emission spectrometer (ICP-OES) (PerkinElmer, Inc., Shelton, CT, USA). The instrumental operating parameters are listed in Table I. Spectral detection for metal analysis by ICP-OES was obtained by measuring the absorbance at the maxi- 
mum wavelength of $238.2 \mathrm{~nm}$ for Fe, $228.6 \mathrm{~nm}$ for Co, $257.6 \mathrm{~nm}$ for $\mathrm{Mn}, 327.4 \mathrm{~nm}$ for $\mathrm{Cu}, 220.4 \mathrm{~nm}$ for $\mathrm{Pb}$, and $206.2 \mathrm{~nm}$ for $\mathrm{Zn}$. A model MWS-3 microwave digestion system (Berghof Co., Germany) with pressure control was utilizied for acid digestion of the samples. Sequential extractions were carried out with a Memmert brand shaker (Memmert GmbH \& Co. KG, Germany) and a Heraeus brand Labofuge-200 model centrifuge (Thermo Fisher Scientific, Germany). A Mettler-Toledo pH meter (Schwerzenbach, Zürich, Switzerland) was utilizied for $\mathrm{pH}$ measurements and adjustment. Ore grinding was done with a Baysan brand jaw crusher and pulverizer (Turkey) and passed through a sieve (Yüksel Kaya Makina, Standard Testing Sieve, Turkey). Ultrapure water was obtained with a Milli-Q ${ }^{\circledR}$ purifier system (Millipore Corporation, USA) and was used throughout this work.

\section{Reagents and Standard Solutions}

All reagents were of analytical grade; acetic acid (Sigma), hydroxyl amonium hyrochloride (Sigma), hydrogen peroxide (Merck), ammonium acetate (Merck), magnesium chlorride, sodium acetate, hydrofluoric acid and nitric acid (Fluka). Preparation of the standard solutions was done by serial dilution of $1000 \mathrm{mg} \mathrm{L}^{-1}$ stock solution of the desired element.

\section{Preparation of Ore Samples}

For this work, the ore samples were obtained from the Keban region in Elaziğ, Turkey. The samples were placed into boxes, then dried in an oven at $20^{\circ} \mathrm{C}$ for 2 hours, broken with a jaw crusher and pulverizer, milled, and passed through a sieve of 100 mesh.

\section{Sequential Extraction \\ Procedures}

\section{Revised BCR Procedure}

A revised sequential extraction procedure for the fractionation of heavy metals, as proposed by the Commission of the European Communities Bureau of Reference (BCR), was applied for the ore sample analysis by ICP-OES.

The revised BCR scheme, a three-step sequential extraction procedure, harmonized and validated the method for the fractionation studies of soils and sediments (13). Compared to the original BCR procedure, the revised protocol involves the use of an increase in concentration of $\mathrm{NH}_{2} \mathrm{OH}-\mathrm{HCl}$ and a lower $\mathrm{pH}$, as described by Mossop and Davidson (31). These extractions are associated to the exchangeable extraction step 1 where $1 \mathrm{~g}$ of ore sample was placed into a $100-\mathrm{mL}$ centrifuge tube, $40 \mathrm{~mL} 0.11 \mathrm{~mol} \mathrm{~L}^{-1}$ acetic acid added, then shaken by a mechanical shaker at $20^{\circ} \mathrm{C}$ at $30 \mathrm{rpm}$ for 16 hours. The extract was separated from the solid residue by centrifugation at $3000 \mathrm{rpm}$ for 20 minutes, decanted into a volumetric flask, diluted with water to $100 \mathrm{~mL}$, and stored in a refrigator at $4^{\circ} \mathrm{C}$ until subsequent analysis.

\section{Atomic Apectroscopy 1 Vol. 39(5), Sept./Oct. 2018}

Reducible-iron/manganese oxides were extraction step 2, which includes the residue from step 1 , to which freshly prepared hydroxylamine hydrochloride ( 40 $\mathrm{mL}, 0.5 \mathrm{~mol} \mathrm{~L}^{-1}$ ) was added, and the solution $\mathrm{pH}$ adjusted to 1.5 with $\mathrm{HNO}_{3}$. The extraction procedure was then performed in the same way as described in step 1 .

Oxidizable-organic matter and sulfides were extraction step 3 where $20 \mathrm{~mL}$ hydrogen peroxide (30\%, pH 2.0) was added carefully to the residue into the centrifuge tube from step 2, and digested at room temperature for 1 hour with occasional manual shaking. The digestion was continued by heating the vessel to $85^{\circ} \mathrm{C}$ in a water bath for 1 hour, then reduced to less than $3 \mathrm{~mL}$ volume by further heating of the uncovered tube. A further aliquot of $10 \mathrm{~mL}$ of hydrogen peroxide was added and the digestion procedure repeated. Then, $50 \mathrm{~mL}$ of ammonium acetate was added to the cool, moist residue and shaken for 16 hours at $20^{\circ} \mathrm{C}$ (the $\mathrm{pH}$ was adjusted to 2.0 with nitric acid). Following, the extract was separated from the solid residue (as described in step 1).

TABLE I

ICP-OES Instrumental Operating Conditions

\begin{tabular}{ll}
\hline Parameters & \\
\hline RF power & $1450 \mathrm{~W}$ \\
Plasma gas flow rate & $15 \mathrm{~L} \mathrm{~min}^{-1}$ \\
Auxiliary gas flow rate & $0.2 \mathrm{~L} \mathrm{~min}^{-1}$ \\
Nebulizer gas flow rate & $0.8 \mathrm{~L} \mathrm{~min}^{-1}$ \\
Sample flow rate & $1.5 \mathrm{~L} \mathrm{~min}^{-1}$ \\
View mode & Axial \\
Read & Peak area \\
Source equilibration time (s) & $15 \mathrm{~s}$ \\
Read delay & $50 \mathrm{~s}$ \\
Replicates & 3 \\
Purge gas & Nitrogen \\
Shear gas & Air \\
Plasma gas & Argon \\
Metal $\lambda$ max (nm) & Fe 238.2, Co 228.6, Mn 257.6 \\
& Cu 327.4, Pb 220.4, Zn 206.2 \\
\hline
\end{tabular}


Finally, step 4 includes a digestion of the residue with aqua regia $\left(\mathrm{HCl} / \mathrm{HNO}_{3}-3: 1\right)$ in a microwave oven for 26 minutes. After microwave digestion, the samples of step 4 were filtered through a filter paper (Whatman No. 1 - Cat. No. 1001-010) and diluted to $100 \mathrm{~mL}$ with ultrapure water.

\section{Modified Tessier Procedure}

In exchangeable step 1 , the fractions extracted were approximately $1 \mathrm{~g}$ ore sample with $10 \mathrm{~mL}$ of $1 \mathrm{M}$ ammonium acetate ( $\mathrm{pH}$ 7.0). The sample was shaken for 1 hour at $150 \mathrm{rpm}$ at $20^{\circ} \mathrm{C}$, then centrifuged at $4000 \mathrm{rpm}$ for 10 minutes. The liquid phase was decanted into a volumetric flask and diluted with $100 \mathrm{~mL}$ ultrapure water. The carbonates were extracted in step 2 . For this purpose, $1 \mathrm{M} 10 \mathrm{~mL}$ acetic acid was added to the residue of fraction 1 . The solution was shaken at $150 \mathrm{rpm}$ for 1 hour, then centrifuged for 10 minutes at $4000 \mathrm{rpm}$ at $20^{\circ} \mathrm{C}$. The liquid phase was decanted into a volumetric flask and diluted with ultrapure water to 100-mL volume. Oxidizable-organic matter and sulfides were extracted in step 3. The residue from fraction 2 was treated with $5 \mathrm{~mL}$ of a $30 \%$ solution of $\mathrm{H}_{2} \mathrm{O}_{2}$, the $\mathrm{pH}$ was adjusted to 2.0 with nitric acid solution. The sample was shaken for 3 hours at $150 \mathrm{rpm}$ at $35^{\circ} \mathrm{C}$. After the sample was centrifuged at 10.000 $\mathrm{rpm}$, it was filtered with filter paper (Whatman No. 1 - Cat No. 1001-010) and diluted to $100 \mathrm{~mL}$ with ultrapure water. Then, $10 \mathrm{~mL}$ aqua regia, $2.5 \mathrm{~mL} \mathrm{HNO}_{3}$ (65\%), and $7.5 \mathrm{~mL} \mathrm{HCl}$ (37\%) were added to the residue and filtered from fraction 3. After microwave digestion, the samples were filtered and diluted to $100 \mathrm{~mL}$ with ultrapure water (13).

\section{RESULTS AND DISCUSSION}

\section{Revised BCR Procedure}

Step 1: $40 \mathrm{~mL} \mathrm{CH}_{3} \mathrm{COOH}$

(0.11 M, pH=7.0)

This step was applied to produce acetate salts of $\mathrm{Fe}, \mathrm{Cu}, \mathrm{Zn}$, $\mathrm{Pb}$, and $\mathrm{Mn}$ and to determine the solubility ratio of these salts in solution. In Table II, it can be seen that these ions in the ore structure could pass to solution at different ratios according to their solubility.

Step 2: $40 \mathrm{~mL} \mathrm{NH} \mathrm{NH}_{2} \mathrm{OH}-\mathrm{HCl}$ (0.5 M, pH=1.5)

In this step, the aim was to create conditions for the passage of metal ions, which includes a high ratio of Fe and Mn to solution by addition of hydroxylamine, a reducing reagent, and hydrochloric acid, both a proton donor and complexing agent. The procedure was chosen due to the fact that Fe mineral is both in hematite and magnetite structure and manganese can be found as $\mathrm{MnO}$ compound.

Step 3: $20 \mathrm{~mL} \mathrm{H}_{2} \mathrm{O}_{2}(30 \%$, $\mathrm{pH}=2.0$ ) and $50 \mathrm{~mL} \mathrm{CH}_{3} \mathrm{COONH}_{4}$ $1 \mathrm{M}, \mathrm{pH}=2.0$

The addition of $\mathrm{H}_{2} \mathrm{O}_{2}$ allows decomposition of the organic substances $\left(\mathrm{CO}_{2}, \mathrm{H}_{2} \mathrm{O}, \mathrm{NOx}\right)$ due to its high oxidizing activity which causes a reduction electrode potential of $1.70 \mathrm{~V}$. This step was carried out to convert sulfur in the sulfur compounds to its elemental form and dissolution of the metal ions by converting them to the highest oxidation state. Since the $\mathrm{pH}$ of the medium is fixed at around 2.0, the acetate salts of the metal compounds may dissolve and pass into the aqueous medium. However, as can be seen from Table II, all metal ions except $\mathrm{Cu}^{1+}$ cannot be dissolved in solution due to the existence of $\mathrm{NH}_{4} \mathrm{CH}_{3} \mathrm{COO}$. Furthermore, it is also thought that all $\mathrm{Cu}^{1+}$ in the ore structure became and dissolved as $\mathrm{Cu}^{2+}$ ions in $\mathrm{NH}_{4} \mathrm{CH}_{3} \mathrm{COO}$ solution.

TABLE II

Results Obtained (mean \pm standard deviation, $\mathbf{n}=3$ ) for Sequential Extraction Procedures

\begin{tabular}{|c|c|c|c|c|c|c|}
\hline $\begin{array}{c}\text { Revised } \\
\text { BCR }\end{array}$ & $\begin{array}{c}\mathrm{Fe} \\
\left(\mathrm{mg} \mathrm{kg}^{-1}\right)\end{array}$ & $\begin{array}{c}\mathrm{Cu} \\
\left(\mathrm{mg} \mathrm{kg}^{-1}\right)\end{array}$ & $\begin{array}{c}\mathrm{Co} \\
\left(\mathrm{mg} \mathrm{kg}^{-1}\right)\end{array}$ & $\begin{array}{c}\mathrm{Pb} \\
\left(\mathrm{mg} \mathrm{kg}^{-1}\right)\end{array}$ & $\begin{array}{c}\mathrm{Zn} \\
\left(\mathrm{mg} \mathrm{kg}^{-1}\right)\end{array}$ & $\begin{array}{c}\mathrm{Mn} \\
\left(\mathrm{mg} \mathrm{kg}^{-1}\right)\end{array}$ \\
\hline Step 1 & $7.10 \pm 0.14$ & $3438 \pm 103$ & $\mathrm{Nd}$ & $0.06 \pm 0.0013$ & $6.10 \pm 0.12$ & $173 \pm 5$ \\
\hline Step 2 & $2514 \pm 50$ & $3286 \pm 66$ & $13.14 \pm 0.26$ & $8.26 \pm 0.16$ & $7.74 \pm 0.14$ & $736 \pm 20$ \\
\hline Step 3 & $\mathrm{Nd}$ & $36.3 \pm 0.72$ & $\mathrm{Nd}$ & $\mathrm{Nd}$ & $\mathrm{Nd}$ & $\mathrm{Nd}$ \\
\hline Step 4 & $458000 \pm 7246$ & $7020 \pm 158$ & $34.78 \pm 0.69$ & $73 \pm 1$ & $118 \pm 2$ & $603 \pm 12$ \\
\hline $\begin{array}{c}\text { Modified } \\
\text { Tessier }\end{array}$ & $\begin{array}{c}\mathrm{Fe} \\
\left(\mathrm{mg} \mathrm{kg}^{-1}\right)\end{array}$ & $\begin{array}{c}\mathrm{Cu} \\
\left(\mathrm{mg} \mathrm{kg}^{-1}\right)\end{array}$ & $\begin{array}{c}\mathrm{Co} \\
\left(\mathrm{mg} \mathrm{kg}^{-1}\right)\end{array}$ & $\begin{array}{c}\mathrm{Pb} \\
\left(\mathrm{mg} \mathrm{kg}^{-1}\right)\end{array}$ & $\begin{array}{c}\mathrm{Zn} \\
\left(\mathrm{mg} \mathrm{kg}^{-1}\right)\end{array}$ & $\begin{array}{c}\mathrm{Mn} \\
\left(\mathrm{mg} \mathrm{kg}^{-1}\right)\end{array}$ \\
\hline Step 1 & $2.82 \pm 0.06$ & $1028 \pm 23$ & $\mathrm{Nd}$ & $\mathrm{Nd}$ & $1.18 \pm 0.02$ & $17.48 \pm 0.35$ \\
\hline Step 2 & $589 \pm 13$ & $5286 \pm 140$ & $3.92 \pm 0.08$ & $244 \pm 7$ & $15.02 \pm 0.45$ & $375 \pm 10$ \\
\hline Step 3 & $792 \pm 24$ & $718 \pm 18$ & $1032 \pm 30$ & $11.36 \pm 0.22$ & $7.10 \pm 0.14$ & $605 \pm 13$ \\
\hline Step 4 & $365800 \pm 6975$ & $668 \pm 17$ & $34.72 \pm 0.67$ & $68 \pm 1$ & $114 \pm 3$ & $648 \pm 15$ \\
\hline
\end{tabular}

Nd: not dedected. 
Step 4: $10 \mathrm{~mL}$ demineralized water and $10 \mathrm{~mL}$ aqua regia $\left(\mathrm{HCl} / \mathrm{HNO}_{3}, 3: 1\right)$

In this step, $\mathrm{HCl} / \mathrm{HNO}_{3}$ solution $(3: 1)$, which was diluted by half with demineralized water, was added to the remaining ore structure (includes the metals that were not dissolved in the previous steps), then the solution was treated in the microwave oven to dissolve them.

\section{Modified Tessier Procedure}

\section{Step 1: $10 \mathrm{~mL} \mathrm{NH}_{4} \mathrm{CH}_{3} \mathrm{COO}$ (1 $\mathrm{M}, \mathrm{pH}=7.0$ ) \\ This study was performed to determine the ions that can pass to the solution by an effective buffering with the addition of $\mathrm{NH}_{4} \mathrm{CH}_{3} \mathrm{COO}$ at $\mathrm{pH}$ 7.0. The values obtained in this study were lower than those obtained by buffering with $\mathrm{CH}_{3} \mathrm{COOH}$ at $\mathrm{pH}$ 7.0.}

Step 2: $10 \mathrm{~mL} \mathrm{CH}_{3} \mathrm{COOH}$ (1 $\mathrm{M}, \mathrm{pH}=5.5$ )

In order to detect the presence of carbonated compounds in the structure, the $\mathrm{pH}$ of $\mathrm{CH}_{3} \mathrm{COOH}$ medium was adjusted to 5.5 and dissolution was performed. As can be seen from Table II, it was observed that $\mathrm{Fe}, \mathrm{Cu}, \mathrm{Co}, \mathrm{Zn}, \mathrm{Pb}$, and $\mathrm{Mn}$ were passed to the solution medium.

Step 3: $5 \mathrm{~mL} \mathrm{H}_{2} \mathrm{O}_{2}(30 \%$, $\mathrm{pH}=2.0$ )

In this step, $\mathrm{H}_{2} \mathrm{O}_{2}$ was added to decompose the organic substances $\left(\mathrm{CO}_{2}, \mathrm{H}_{2} \mathrm{O}, \mathrm{NOx}\right)$ by its high oxidizing activity which causes a reduction electrode potential of $1.70 \mathrm{~V}$. It is aimed to convert the sulfur in the sulfur compounds to its elemental form and dissolve the metal ions by converting them to the highest oxidation state. The acetate salts of the metal compounds can be dissolved and passed into the aqueous medium since the $\mathrm{pH}$ is fixed around 2.0.
Step 4: $10 \mathrm{~mL}$ demineralized water and $10 \mathrm{~mL}$ aqua regia $\left(\mathrm{HCl} / \mathrm{HNO}_{3}, 3: 1\right)$

This step is the same as step 4 in the revised BCR procedure. The remaining ore structure was also treated with $\mathrm{HCl} / \mathrm{HNO}_{3}$ solution (3:1), which was diluted by half with demineralized water for the metals that were not dissolved in the previous steps, and then the solution was put in a microwave oven to dissolve them.

\section{CONCLUSION}

When the two studied procedures are examined, it can be seen that there are differences in the bonding forms of the metals to the ore and the properties of the reactants. Because of these differences, the amount of metals passing to the solution are different for both procedures.

When the first steps of the modified Tessier and the revised BCR procedures are compared, it can be seen that the ions pass to the solution at lower values in the modified Tessier procedure. In the second step of the revised BCR procedure, it is thought that the ions can pass to the solution depending on their reduction, oxidation, and complexation properties. $\mathrm{Mn}$ is more likely to be dissolved in the second step of the revised BCR than in the other steps. The reason may be that Mn changes to $\mathrm{MnO}$ due to the hematite and magnetite structure of the ore. In the second step of the modified Tessier procedure, the presence of carbonated compounds in the ore structure and the passage of all studied ions to solution were observed. If the second steps are compared, it can be seen that the revised $\mathrm{BCR}$ procedure is better for dissolution of the $\mathrm{Fe}, \mathrm{Co}$, and $\mathrm{Mn}$ ions; however, the modified Tessier procedure for dissolution of $\mathrm{Cu}, \mathrm{Pb}$, and $\mathrm{Zn}$. In the third step of the revised $\mathrm{BCR}$ procedure, only the $\mathrm{Cu}$ ion passes to the solution. The rea-

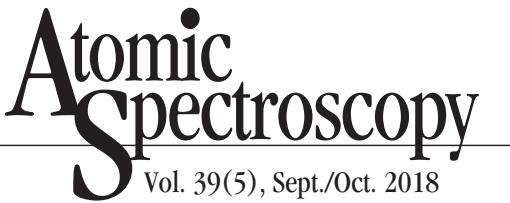

son may be that all $\mathrm{Cu}^{1+}$ in the ore structure became and dissolved as $\mathrm{Cu}^{2+}$ ions in the $\mathrm{NH}_{4} \mathrm{CH}_{3} \mathrm{COO}$ solution. However, in the third step of the modified Tessier procedure, all of the metal ions in the sample dissolved and passed to the solution due to $\mathrm{H}_{2} \mathrm{O}_{2}$ which is a strong oxidizing agent, and the $\mathrm{pH}$ of the solution is fixed at around 2.0. The final steps of both procedures were carried out to pass the ions to the solution which are found as mineral structure and cannot dissolve.

All in all, if the revised BCR and the modified Tessier procedures are compared, it seems that the modified Tessier procedure has more advantages due to the fact that the revised BCR procedure needs more chemicals and takes a longer time to complete. However, the appropriate procedure changes depending on the metal. According to the results of this study, $\mathrm{Cu}, \mathrm{Pb}$, and $\mathrm{Mn}$ ions passed to solution better in the modified Tessier procedure, but the $\mathrm{Fe}, \mathrm{Cu}, \mathrm{Zn}$ ions were more dissolved in the revised BCR procedure.

Receved December 8, 2017.

\section{REFERENCES}

1. M. Zemberyova, J. Bartekova, and I. Hagarova, Talanta 70, 973 (2006).

2. E. Merian (Ed.), Metals and their Compounds in the Environment: Occurrence, Analysis and Biological Relevance, VCH, Weinheim, Germany, p. 1373 (1991).

3. J. Unda-Calvo, M. Martínez-Santos, and E. Ruiz-Romera, Ecotoxicology and Environmental Safety 138, 260 (2017).

4 D. L. Lake, P. W.W. Kirk, and J.N. Lester, J. Environ. Qual. 13, 175 (1984).

5. E. Fernández-Ondoño, G. Bacchetta, A. M. Lallena, F. B. Navarro, I. Ortiz, and M. N. Jiménez, J. Geochem. Exploration 
172, 133 (2017).

6. F. Degryse, E. Smolders, and D.R. Parker, Eur. J. Soil Sci. 60, 590 (2009).

7. M. M. Abreu, E. S. Santos, M. Ferreira, and M.C.F. Magalhães, J. Geochem. Explor. 113, 86 (2012).

8. I. Aydın, F. Aydın, and C. Hamamci, Microchem. j. 108, 64 (2013).

9. M.Z. Duz, K.S. Celik, I. Aydin, S. Erdogan, F. Aydin, and C. Hamamci, At. Spectrosc. 33, 78 (2012).

10. B. Gunduz, F. Aydin, I. Aydin, and C. Hamamci, Microchem. J. 98 (1), 72 (2011).

11. X. Zhou, C. Li, J. Li, H. Liu, and S. Wu, Hydrometallurgy 99, 97 (2009).

12. E. Margui, V. Salvado, I. Queralt, and M. Hidalgo, Anal. Chim. Acta 524, 151 (2004).

13. E. D. Van Hullebusch, S. Utomo, M. H. Zandvoort, and P.N.L. Lens, Talanta 65, 549, (2005).

14. A. V. Filgueiras, I. Lavilla, and C. Bendicho, J. Environ. Monit. 4, 823 (2002).

15. S. Orecchio and G. Polizzotto, Microchem. J. 110, 452 (2013).

16. D. Aubert, A. Probst, and P. Stille, Appl. Geochem. 19, 899 (2004).

17. R. Larios, R. Fernandez-Martinez, and I. Rucandio, Anal. Bioanal. Chem 402, 2909 (2012).

18. J. Lucey, A. Gouzy, D. Boust, L. Leon Vintro, L. Bowden, P. Finegan, P. Kershaw, and P. Mitchell, Appl. Radiat. Isot. 60, 379 (2004).

19. A. Tessier, P.G.C. Camppbell, and M. Blsson, Anal. Chem. 51, 844 (1979).

20. W. Salomons andU. Forstner, Metals in the Hydrogeocycle, SpringerVerlag, Berlin, Germany (1984).

21. M. Kersten and U. Forstner, Water Sci. Technol.18, 121 (1986).

22. R.C. Stover, L.E. Sommers, D.J. Silvera, J. Water Pollut. Con. F. 48, 2165 (1976).

23. J.L. Gomez Ariza, I. Giraldez, D. Sanchez-Rodas, and E. Morales,
The Science of the Total Environment 246, 271 (2000).

24. A. J. Zimmerman and D.C. Weindorf, Int. J. of Anal. Chem. 387803, 1 (2010).

25. I. Maiz, I. Arambarri, R. Garcia, and E. Millan, Environ. Pollut. 110, 3 (2000).

26. E. Fernandez-Ondono, G. Bachetta, A.M. Lallena, F.B.Navarro, I. Ortiz, and M.N. Jimenez, J. Geochem. Expl. 172,133 (2017).

27. A. Sherry, J. Faye, M. Richards, A. M. Gallardo, K. R. Campbell, and R. Sudowe, J. Radioanal. Nucl. Chem, 312, 37 (2017).

28. A.M. Ure, P.H. Quevauviller, H. Muntau, and B. Griepink, Int. J. of Environ. Anal. Chem. 51, 135 (1993).

29. K. Nemati, N.Kartini,A. Bakar, and M.R. Abas, Microchem. J. 91, 227 (2009).

30. M.B. Osuna, E.D.van Hullebusch, M.H. Zandvoort, J. Iza, and P.N.L. Lens, J. Environ. Qual. 33, 1256 (2004).

31. K.F. Mossop and C.M. Davidson, Anal. Chim. Acta 478, 111 (2003). 